\title{
Physiotherapy and intermittent positive-pressure ventilation of chronic bronchitis
}

\author{
D A G NEWTON, H G BEVANS
}

British Medical fournal, 1978, 2, 1525-1528

\section{Summary and conclusions}

Patients aged over 45 admitted to hospital with exacerbations of chronic bronchitis alone or in association with cor pulmonale, pneumonia, or respiratory failure were placed in one of three groups (men with hypoxia, men without hypoxia, and women). Patients within these groups were then randomly allocated to receive either standard drug treatment alone or standard drug treatment plus intermittent positive-pressure ventilation (IPPV). No significant differences occurred between the controls and patients receiving physiotherapy and IPPV in any group.

We conclude that when a patient with chronic bronchitis and respiratory failure is deteriorating emphasis should be on correct diagnosis, fluid electrolyte balance, and nutrition together with oxygen treatment when necessary, rather than on additional physiotherapy.

\section{Introduction}

Acute exacerbations of chronic bronchitis are characterised by purulent sputum, airflow obstruction, and often hypoxaemia and hypercapnia. ${ }^{1}$ In the United Kingdom physiotherapy is conventionally given to facilitate the removal of secretions. Physical adjuncts have been recommended, ${ }^{2}$ though the evidence remains scant. ${ }^{3}$ Slow deep breathing in emphysema, ${ }^{4}$ breathing exercises, ${ }^{5}$ voluntary hyperventilation, and intermittent positivepressure ventilation (IPPV) all have a beneficial effect on blood gas tensions, IPPV doing so at lower oxygen cost. ${ }^{6}$ A Swedish study on bronchitic exacerbations showed no difference between patients given physiotherapy and controls in defervescence of fever or sputum volume $;^{7}$ and a laboratory study showed no clear benefit of physiotherapy in acutely ill people. ${ }^{8}$ We have carried out a randomised controlled trial of physiotherapy and IPPV in patients admitted to this hospital irrespective of the severity of their bronchitic exacerbations.

\section{Patients and methods}

Patients of either sex were eligible for the trial if they had acute exacerbations of chronic bronchitis, were aged 45 or over, and were admitted between 1 November 1977 and 1 May 1978. An acute exacerbation of bronchitis was defined as an increase in cough, phlegm, or breathlessness for over 24 hours occurring in a patient with chronic bronchitis. ${ }^{9}$ Male patients were divided into two groups on the basis of their arterial oxygen tension $\left(\mathrm{PaO}_{2}\right)$ on admission: group 1 comprised those whose $\mathrm{PaO}_{2}$ was over $8.0 \mathrm{kPa}(60 \mathrm{~mm} \mathrm{Hg})$ and group 2 those with $\mathrm{PaO}_{2}<8.0 \mathrm{kPa}$. The women in the trial formed group 3 . We then randomly allocated patients in each group to treatment with standard drug regimens plus physiotherapy and IPPV or standard drug regimens alone (controls), using prearranged

St James's University Hospital, Leeds LS9 7TF

D A G NEWTON, MB, MRCP, senior medical registrar

H G BEVANS, PHD, head of department of clinical psychology sealed envelopes. Patients were excluded if they had renal, hepatic, or cardiac failure (other than cor pulmonale); malignant disease; tuberculosis; bronchial asthma or bronchiectasis; unstable angina; a myocardial infarction within the previous month; anaemia with a haemoglobin concentration under $11 \mathrm{~g} / \mathrm{dl}$; simple bronchitis with mucus hypersecretion but no airflow obstruction (ratio of forced expiratory volume in one second to vital capacity $\left(\mathrm{FEV}_{1}: \mathrm{VC}\right)$ less than $70 \%$ predicted, and in this study $\mathrm{FEV}_{1}$ less than $50 \%$ predicted); or a mental or physical state suggesting inability to co-operate in the trial.

The following factors were determined on admission: full blood count, erythrocyte sedimentation rate, urea electrolyte concentrations, liver function, $\mathrm{PaO}_{2}, \mathrm{FEV}_{1}$, and VC. Sputum culture and smear, electrocardiography, and chest $x$-ray examinations were also carried out. Viral antibodies were determined and blood culture performed when pneumonic consolidation was present. $\mathrm{PaO}_{2}$ was measured in all patients, breathing air, on admission and discharge. The 24-hour sputum volume was measured daily, and $\mathrm{FEV}_{1}$ :VC twice daily (at 0900 and 1500 ). $\mathrm{PaO}_{2}$ in hypoxic patients was measured daily for the first week on oxygen.

\section{STANDARD TREATMENT}

Patients received the following treatment: (1) antibiotics-oral tetracycline $500 \mathrm{mg}$ four times daily, or ampicillin $500 \mathrm{mg}$ four times daily if they were sensitive to tetracycline or had a blood urea concentration over $8 \mathrm{mmol} / 1(48 \mathrm{mg} / 100 \mathrm{ml})$. Any appropriate antibiotic was given for consolidation; (2) bronchodilators-salbutamol inhalation, two puffs six-hourly; (3) diuretics-frusemide up to $120 \mathrm{mg}$ by mouth, then intravenously as necessary to achieve diuresis; and (4) oxygen- $24 \%$ by Ventimask at $41 /$ min for all patients with hypoxia.

\section{PHYSIOTHERAPY AND IPPV}

Physiotherapy was given in a standard fashion ${ }^{10}$ by means of conventional methods ${ }^{11}$ to all patients allocated to receive it. It was given three times daily for 10-15 minutes depending on patient tolerance. IPPV was given at 0900 by a physiotherapist and at 1400 and 1800 by a nurse, using $4 \mathrm{ml}$ nebulised physiological saline over about 15 minutes.

\section{CLINICAL RECORDS}

These comprised (1) temperature, taken four times daily; (2) daily measurement of weight in patients with oedema; (3) daily eating score (nothing $=0$, being choosy $=1$, eating $\operatorname{most}=2$, eating all $=3$ ); (4) sleep score (no sleep $=0$, under two hours $=1$, most of night $=2$, all night =3); (5) results of an MRC bronchitis questionnaire recorded as soon as possible after admission (CB or HP); (6) results of Neuroticism Score Questionnaire (NSQ; Institute for Personality and Ability Testing, Illinois, USA), which was completed on admission and discharge; and (7) daily measurement of the distance walked in one minute along the corridor, unaided and self-paced.

\section{Results}

One hundred and two patients were admitted with acute exacerbations of chronic bronchitis without apparent complicating disease. Six had had physiotherapy before randomisation and so were excluded, and 12 were excluded after randomisation, due to misdiagnosis (five) or complicating diseases (seven). Of the remaining 84 patients, four died and one was ventilated (see table V). Table I summarises the clinical data for these 79 patients. Abnormalities of the electrocardiographs and chest radiographs were evenly matched. Figures 1 
and 2 show individual changes in $\mathrm{PaO}_{2}$ and $\mathrm{FEV}$ between admission and discharge in all patients in group 2 . The difference in changes between patients receiving physiotherapy and IPPV and controls was not significant. Figure 3 shows the relation between $\mathrm{FEV}_{1}$ and arterial carbon dioxide pressure $\left(\mathrm{PaCO}_{2}\right)$ on admission in the same patients. Considering all the patients, the only difference was an improvement in $\mathrm{PaO}_{2}$ significant at the $5 \%$ level in favour of the patients in group 1 receiving physiotherapy and the controls in group 2 (tables II and III). Mean sputum volumes were greater in patients in groups 1 and 2 receiving physiotherapy and IPPV and group 3 controls. Patients receiving physiotherapy in group 1 produced significantly more sputum in the last three days in hospital than their respective controls $(P<0.05$; table IV).

Table $\mathrm{V}$ shows the deaths and morbidity in hospital, and late morbidity and mortality. Durations of hospital stay were similar between patients receiving physiotherapy and IPPV and controls (table VI), as were eating, sleeping, exercise, and NSQ score. Patients eating well on day $1($ score $=3$ ) had the shortest stay, and of those

TABLE I-Clinical details of patients in the three groups, excluding those who died or received ventilation

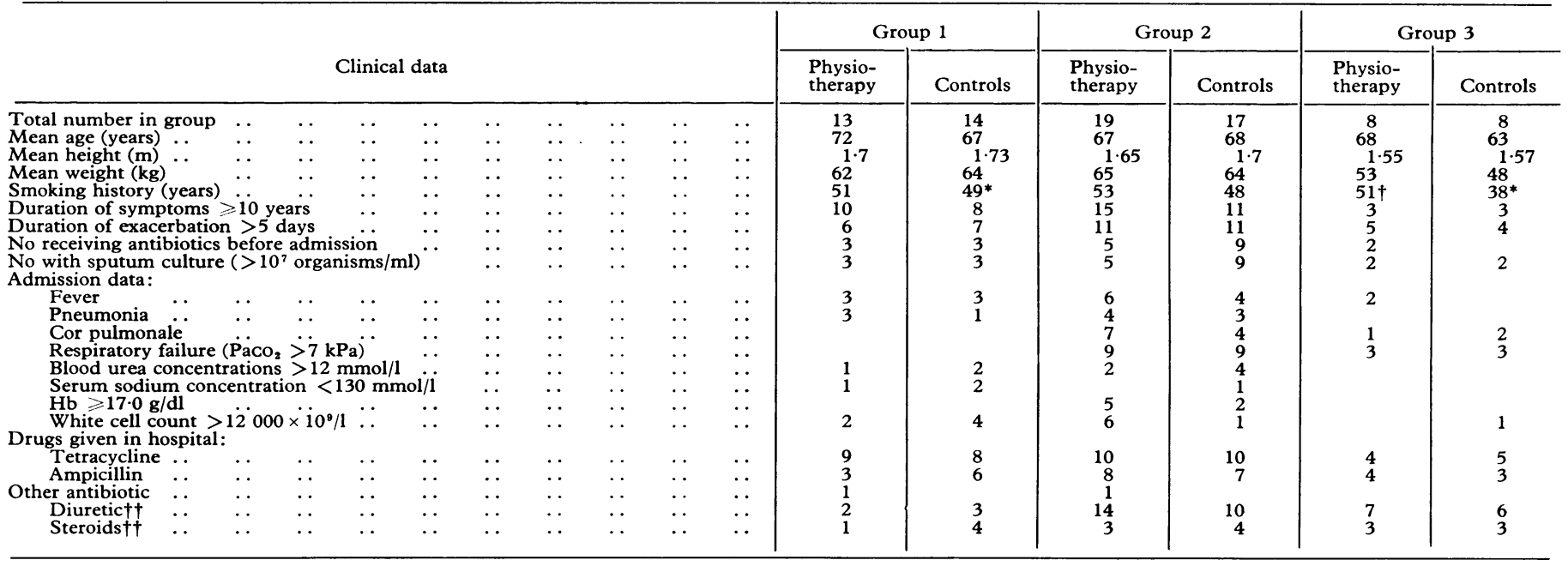

* One non-smoker in group. †Two non-smokers in group. ††Patients taking diuretics or steroids on admission continued with these drugs.

Conversion: SI to traditional units-Paco $: 1 \mathrm{kPa} \approx 0.133 \mathrm{~mm} \mathrm{Hg}$. Urea: $1 \mathrm{mmol} / \mathrm{l} \approx 6 \mathrm{mg} / 100 \mathrm{ml}$. Sodium: $1 \mathrm{mmol} / \mathrm{l}=1 \mathrm{mEq} / \mathrm{l}$

TABLE II-Mean $( \pm S D)$ values of forced expiratory volume in one second (FEV $\left.V_{1}\right)$ and vital capacity (VC) on admission and discharge in patients receiving physiotherapy and IPPV and controls

\begin{tabular}{|c|c|c|c|c|c|c|c|c|}
\hline & \multicolumn{2}{|c|}{$\mathrm{FEV}_{1}(\mathrm{l})$} & \multirow{2}{*}{$\begin{array}{l}\text { Change in } \\
\mathrm{FEV}_{1}(\mathrm{l})\end{array}$} & \multirow{2}{*}{$t$} & \multicolumn{2}{|c|}{ VC (1) } & \multirow{2}{*}{$\begin{array}{c}\text { Change in } \\
\text { VC (1) }\end{array}$} & \multirow{2}{*}{$t$} \\
\hline & Admission & Discharge & & & Admission & Discharge & & \\
\hline $\begin{array}{l}\text { Group 1 } \\
\text { Group } 2\end{array}\left\{\begin{array}{l}\text { Physiotherapy }(n=13) \\
\text { Control }(n=14) \\
\text { Physiotherapy }(n=19) \\
\text { Control }(n=17)\end{array}\right.$ & $\begin{array}{l}0 \cdot 8 \pm 0.4 \\
0 \cdot 8 \pm 0.4 \\
0 \cdot 8 \pm 0 \cdot 3 \\
0 \cdot 6 \pm 0 \cdot 3 \\
0 \cdot 5 \pm 0.3 \\
0.5 \pm 0.3\end{array}$ & $\begin{array}{l}1 \cdot 2 \pm 0 \cdot 6 \\
1 \cdot 5 \pm 0 \cdot 8 \\
1 \cdot 1 \pm 0 \cdot 5 \\
1 \cdot 0 \pm 0 \cdot 6 \\
0 \cdot 8 \pm 0 \cdot 3 \\
0 \cdot 7 \pm 0 \cdot 3\end{array}$ & $\begin{array}{l}+0.4 \\
+0.7 \\
+0.3 \\
+0.4 \\
+0.3 \\
+0.2\end{array}$ & $\left\{\begin{array}{l}1 \cdot 77 ; \mathrm{NS} \\
1 \cdot 2 ; \mathrm{NS} \\
0 \cdot 37 ; \mathrm{NS}\end{array}\right.$ & $\begin{array}{l}1 \cdot 8 \pm 0 \cdot 8 \\
1 \cdot 8 \pm 0.9 \\
1 \cdot 6 \pm 0 \cdot 6 \\
1 \cdot 4 \pm 0 \cdot 9 \\
1 \cdot 0 \pm 0.4 \\
1 \cdot 3 \pm 0 \cdot 6\end{array}$ & $\begin{array}{l}2 \cdot 5 \pm 0 \cdot 8 \\
2 \cdot 8 \pm 0.8 \\
2 \cdot 3 \pm 0 \cdot 6 \\
2 \cdot 2 \pm 1 \cdot 0 \\
1 \cdot 5 \pm 0 \cdot 3 \\
1 \cdot 8 \pm 0.8\end{array}$ & $\begin{array}{l}+0.7 \\
+1.0 \\
+0.7 \\
+0.8 \\
+0.5 \\
+0.5\end{array}$ & $\left\{\begin{array}{l}0.94 ; \mathrm{NS} \\
0.63 ; \mathrm{NS} \\
0.31 ; \mathrm{NS}\end{array}\right.$ \\
\hline
\end{tabular}

NS $=$ Not significant

TABLE III-Mean $( \pm S D)$ arterial oxygen $\left(\mathrm{PaO}_{2}\right)$ and carbon dioxide $\left(\mathrm{PaCO}_{2}\right)$ pressures on admission and discharge in all patients $($ breathing air)

\begin{tabular}{|c|c|c|c|c|c|c|c|c|}
\hline & \multicolumn{2}{|c|}{$\mathrm{PaO}_{2}(\mathrm{kPa})$} & \multirow{2}{*}{$\begin{array}{l}\text { Change in } \\
\mathrm{PaO}_{2}(\mathrm{kPa})\end{array}$} & \multirow{2}{*}{$t$} & \multicolumn{2}{|c|}{$\mathrm{PaCO}_{2}(\mathrm{kPa})$} & \multirow{2}{*}{$\begin{array}{c}\text { Change in } \\
\mathrm{PaCO}_{2}(\mathrm{kPa})\end{array}$} & \multirow{2}{*}{$t$} \\
\hline & Admission & Discharge & & & Admission & Discharge & & \\
\hline 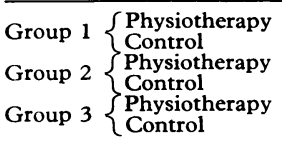 & $\begin{array}{l}9 \cdot 3 \pm 1 \cdot 2 \\
8 \cdot 9 \pm 1 \cdot 0 \\
6 \cdot 1 \pm 1 \cdot 1 \\
6 \cdot 1 \pm 0 \cdot 9 \\
7 \cdot 6 \pm 1 \cdot 2 \\
8 \cdot 1 \pm 2 \cdot 6\end{array}$ & $\begin{array}{r}9 \cdot 5 \pm 0.9 \\
10 \cdot 3 \pm 1.6 \\
7.6 \pm 1.0 \\
7.7 \pm 1 \cdot 1 \\
9 \cdot 0 \pm 1.2 \\
7.9 \pm 1.6\end{array}$ & $\begin{array}{l}+0.2 \\
+1.4 \\
+1.5 \\
+1.6 \\
+1.4 \\
-0.2\end{array}$ & $\left\{\begin{array}{l}2 \cdot 06^{*} \\
0 \cdot 19 ; \mathrm{NS} \\
2 \cdot 2^{* *}\end{array}\right.$ & $\begin{array}{l}5 \cdot 0 \pm 1 \cdot 0 \\
5 \cdot 2 \pm 1 \cdot 1 \\
6 \cdot 7 \pm 2 \cdot 0 \\
6 \cdot 8 \pm 2 \cdot 0 \\
6 \cdot 2 \pm 1 \cdot 4 \\
6 \cdot 3 \pm 1 \cdot 9\end{array}$ & $\begin{array}{l}4 \cdot 7 \pm 0 \cdot 6 \\
4 \cdot 7 \pm 0 \cdot 7 \\
6 \cdot 1 \pm 1 \cdot 7 \\
6 \cdot 5 \pm 1 \cdot 3 \\
5 \cdot 8 \pm 1 \cdot 4 \\
5 \cdot 7 \pm 1 \cdot 3\end{array}$ & $\begin{array}{l}-0.3 \\
-0.5 \\
-0.6 \\
-0.3 \\
-0.4 \\
-0.6\end{array}$ & $\left\{\begin{array}{l}0.5 ; \mathrm{NS} \\
0.7 ; \mathrm{NS} \\
1 \cdot 1 ; \mathrm{NS}\end{array}\right.$ \\
\hline
\end{tabular}

$\mathrm{NS}=$ Not significant.
$* \mathrm{P}=0 \cdot 047 ; * \mathrm{P}=0 \cdot 04$.

Conversion: SI to traditional units: $\mathrm{PaO}_{2}$ and $\mathrm{PaCO}_{2}: 1 \mathrm{kPa} \approx 0 \cdot 133 \mathrm{~mm} \mathrm{Hg}$.

TABLE IV-Mean ( $\pm S E$ of mean) sputum volume $(m l)$ in all patients during first and last three days in hospital

\begin{tabular}{|c|c|c|c|c|c|c|}
\hline & \multicolumn{2}{|c|}{ Group 1} & \multicolumn{2}{|c|}{ Group 2} & \multicolumn{2}{|c|}{ Group 3} \\
\hline & $\begin{array}{l}\text { Physiotherapy } \\
\quad(n=13)\end{array}$ & $\begin{array}{l}\text { Controls } \\
(n=14)\end{array}$ & $\begin{array}{c}\text { Physiotherapy } \\
(n=19)\end{array}$ & $\begin{array}{l}\text { Controls } \\
(\mathrm{n}=17)\end{array}$ & $\begin{array}{l}\text { Physiotherapy } \\
(\mathrm{n}=8)\end{array}$ & $\begin{array}{c}\text { Controls } \\
(n=8)\end{array}$ \\
\hline $\begin{array}{l}\text { First three days } \\
\text { Last three days }\end{array}$ & $\begin{array}{l}23 \cdot 9 \pm 4 \cdot 3 \\
23 \cdot 2 \pm 3 \cdot 0^{*}\end{array}$ & $\begin{array}{r}18 \cdot 1 \pm 4 \cdot 7 \\
9 \cdot 5 \pm 2 \cdot 6 *\end{array}$ & $\begin{array}{l}32 \cdot 0 \pm 7 \cdot 2 \\
22 \cdot 2 \pm 4 \cdot 4\end{array}$ & $\begin{array}{l}23 \cdot 8 \pm 4 \cdot 2 \\
20 \cdot 9 \pm 5 \cdot 4\end{array}$ & $\begin{array}{l}6 \cdot 4 \pm 3 \cdot 5 \\
4 \cdot 2 \pm 1 \cdot 8\end{array}$ & $\begin{array}{l}13 \cdot 3 \pm 5 \cdot 4 \\
10 \cdot 8 \pm 4 \cdot 4\end{array}$ \\
\hline
\end{tabular}

${ }^{*} \mathrm{P}<0.05$ for change in sputum volume between these two groups (non-parametric analysis using Mann-Whitney $U$ test). All other changes not significant. 
TABLE $\mathrm{v}-$ Morbidity and mortality of patients in each group during hospital stay and within three months after discharge

\begin{tabular}{|c|c|c|c|}
\hline & No of patients & Clinical details & Outcome \\
\hline \multicolumn{4}{|c|}{ Morbidity and mortality while patients in hospital } \\
\hline Physiotherapy, group 3 & $1($ aged 80$)$ & Non-hypoxic. Weight $105 \mathrm{~kg}$ & Died 8 days after admission. Necropsy showed bronchitis \\
\hline Physiotherapy, group 2 & 1 (aged 60) & On admission: $\mathrm{PaO}_{2} 5.6 \mathrm{kPa} ; \mathrm{PaCO}_{2} 10.5 \mathrm{kPa} ; \mathrm{FEV}_{1} 0.21$ & Died 1 hour after ventilation. Necropsy showed bilateral \\
\hline Control, group 3 & 1 (aged 65) & On admission: $\mathrm{PaO}_{2} 6.0 \mathrm{kPa} ; \mathrm{PaCO}_{2} 8.5 \mathrm{kPa}^{2} \mathrm{FEV}_{1} 0.41$ & $\begin{array}{l}\text { pneumothorax } \\
\text { Died } 3 \text { hours after ventilation. Necropsy showed chronic }\end{array}$ \\
\hline Control, group 2 & 1 (aged 84) & On admission: $\mathrm{PaO}_{2} 5 \cdot 2 \mathrm{kPa}^{2} \mathrm{PacO}_{2} 9 \cdot 2 \mathrm{kPa} ; \mathrm{FEV}_{1} 0.61$ & $\begin{array}{l}\text { bronchitis } \\
\text { Died } 3 \text { weeks after admission of respiratory failure. }\end{array}$ \\
\hline Control, group 3 & $1($ aged 56$)$ & $\begin{array}{l}\text { On admission: } \mathrm{PaO}_{2} 4 \cdot 0 \mathrm{kPa} ; \mathrm{PaCO}_{2} 8.5 \mathrm{kPa} \text {. Groaning } \\
\text { respiration. Ileus. Ventilated at } 16 \text { hours }\end{array}$ & Recovered and returned to work. \\
\hline \multicolumn{4}{|c|}{ Morbidity and mortality within three months after discharge } \\
\hline $\begin{array}{l}\text { Physiotherapy, } \\
\text { groups } 1-3\end{array}$ & $\begin{array}{r}9 \\
33 \\
11\end{array}$ & $\begin{array}{l}11 \text { readmissions } \\
\text { Died } \\
14 \text { chest infections }\end{array}$ & $\begin{array}{l}\text { Deaths due to cor pulmonale (group 2), respiratory } \\
\text { failure (group 2), myocardial infarction (group 1) }\end{array}$ \\
\hline Control, groups $1-3$ & $\begin{array}{l}6 \\
4 \\
8\end{array}$ & $\begin{array}{l}7 \text { readmissions } \\
\text { Died } \\
11 \text { chest infections }\end{array}$ & $\begin{array}{l}\text { Deaths due to cor pulmonale (group 2), renal failure } \\
\text { but cause unknown (group 2), pneumothorax } \\
\text { (group 2), unknown causes (group 1) }\end{array}$ \\
\hline
\end{tabular}

Conversion: SI to traditional units $-\mathrm{PaO}_{2}$ and $\mathrm{Paco}_{2}: 1 \mathrm{kPa} \approx 0.133 \mathrm{~mm} \mathrm{Hg}$.

TABLE VI-Mean $( \pm S D)$ duration of hospital stay in days

\begin{tabular}{|c|c|c|c|c|c|c|}
\hline & \multicolumn{2}{|c|}{ Group 1} & \multicolumn{2}{|c|}{ Group 2} & \multicolumn{2}{|c|}{ Group 3} \\
\hline & $\begin{array}{l}\text { Physiotherapy } \\
\quad(\mathrm{n}=13)\end{array}$ & $\begin{array}{l}\text { Control } \\
(n=14)\end{array}$ & $\begin{array}{l}\text { Physiotherapy } \\
(\mathrm{n}=19)\end{array}$ & $\begin{array}{l}\text { Control } \\
(n=17)\end{array}$ & $\begin{array}{l}\text { Physiotherapy } \\
\quad(\mathrm{n}=8)\end{array}$ & $\begin{array}{c}\text { Control } \\
(\mathrm{n}=8)\end{array}$ \\
\hline Days in hospital: & $8 \cdot 1 \pm 3 \cdot 3$ & $7 \cdot 9+1 \cdot 8$ & $9 \cdot 3 \pm 3 \cdot 2$ & $9 \cdot 1 \pm 2 \cdot 6$ & $11 \cdot 6 \pm 7 \cdot 6$ & $10 \cdot 4 \pm 3 \cdot 6$ \\
\hline
\end{tabular}

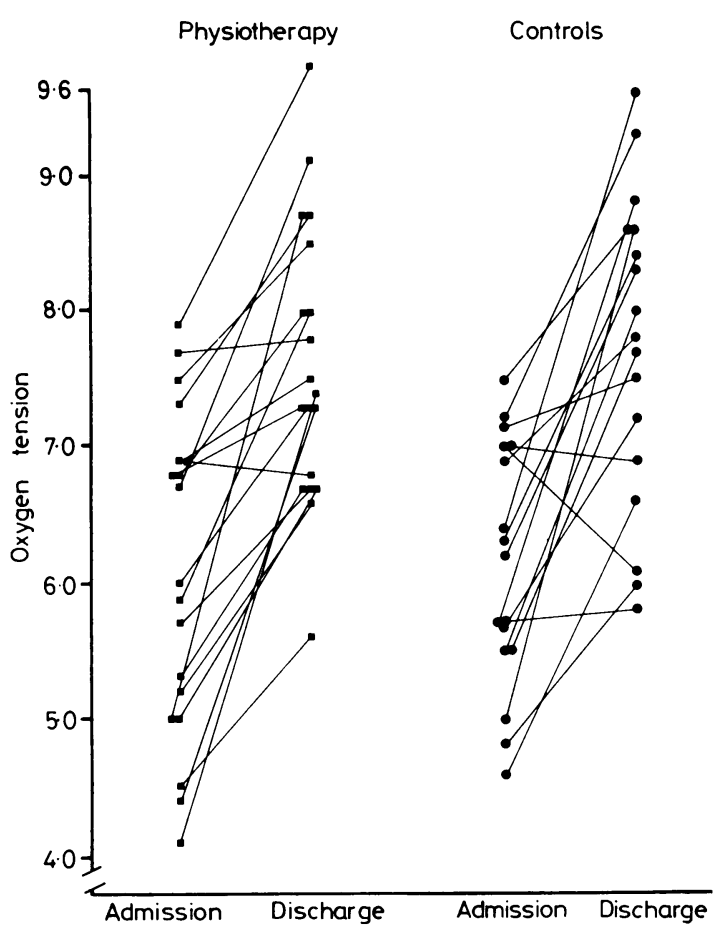

FIG 1-Changes in arterial oxygen tension during hospital stay in hypoxic male patients receiving physiotherapy and IPPV and controls (group 2).

eating well by day 3, only one was in hospital for more than nine days. Patients not eating well till day 5 were in hospital for 10-15 days. Poor sleeping was of little prognostic value in individual cases. All patients who ultimately died had been poor sleepers, but so had several who eventually did well. Daily increase in distance walked in the self-paced exercise test was a reliable index of improvement and had a positive correlation with $\mathrm{VC}(\mathrm{r}=0.46, \mathrm{P}<0.05$; fig 4). The NSQ showed a trend towards more positive personality characteristics, with little effect on anxiety (fig 5 ).

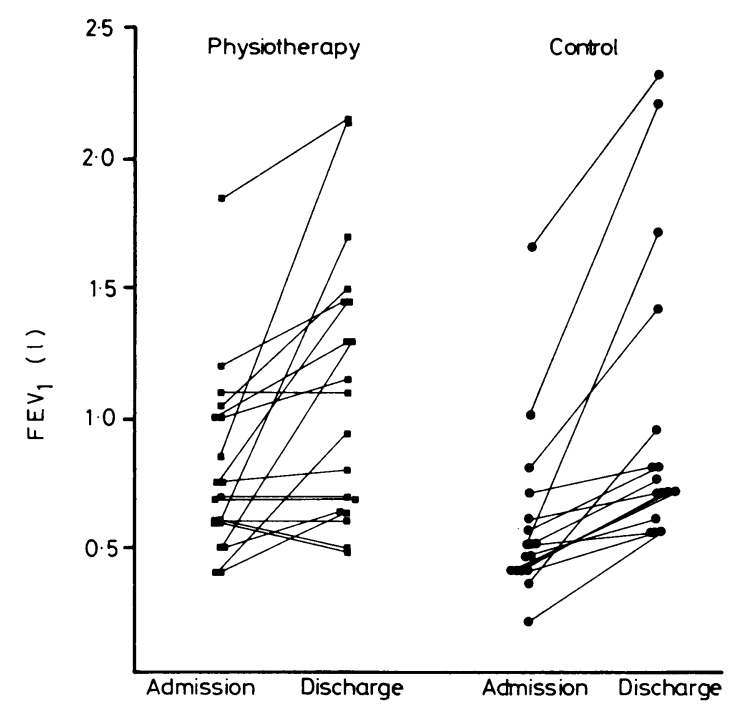

FIG 2-Changes in $\mathrm{FEV}_{1}$ during hospital stay in hypoxic male patients receiving physiotherapy and IPPV and controls (group 2).

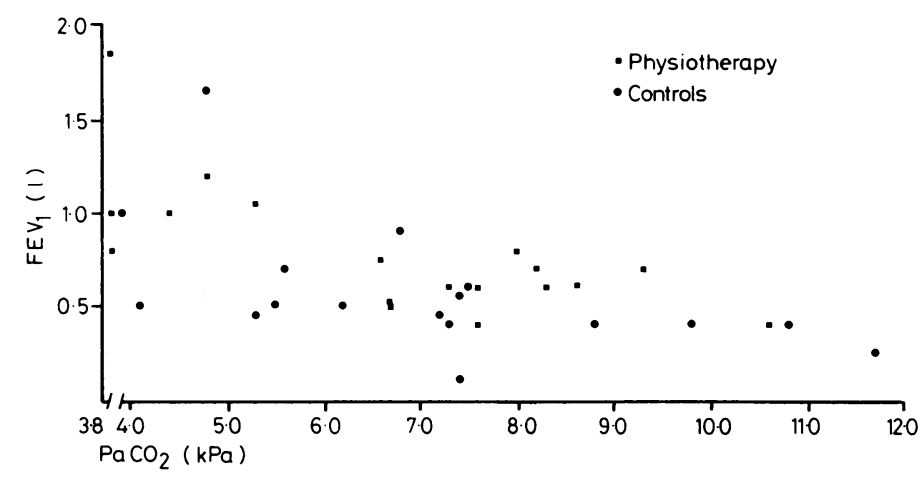

FIG 3-Relation between $\mathrm{FEV}_{1}$ and $\mathrm{PaCO}_{2}$ on admission in all patients in group 2. Patients who died are excluded.

Conversion: SI to traditional units- $\mathrm{PaCO}_{2}: 1 \mathrm{kPa} \approx 0.133 \mathrm{~mm} \mathrm{Hg}$. 


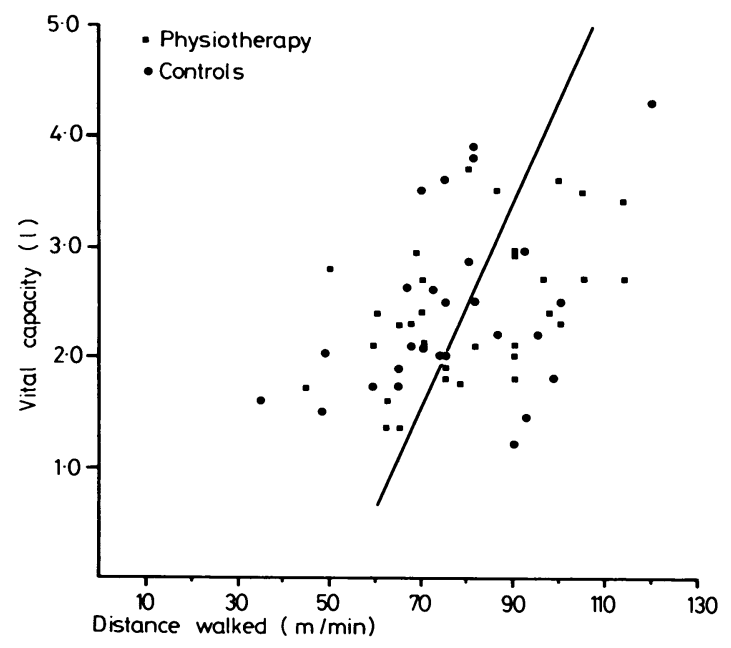

FIG 4-Relation between vital capacity and distance walked in one minute on discharge in all male patients. Four patients were excluded, due to osteoarthritis of hip (two), artificial limb (one), and acute gout (one).

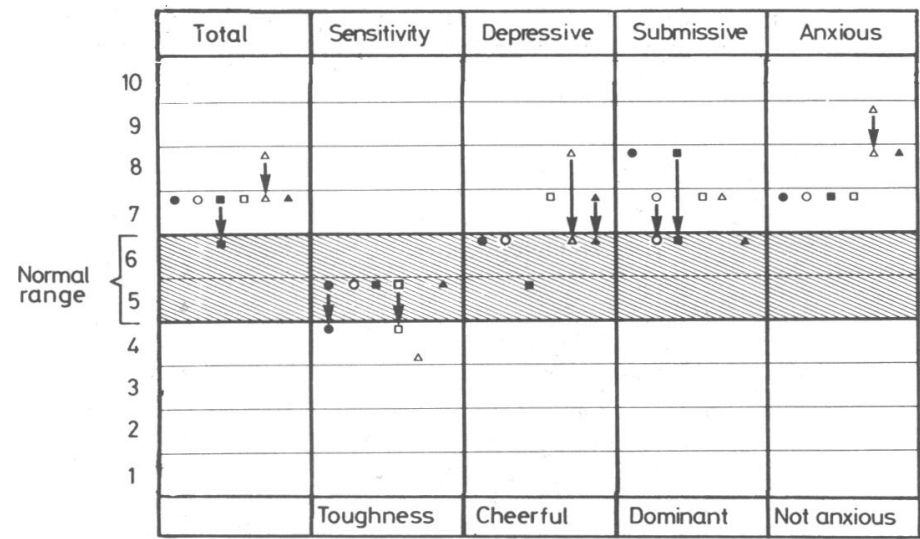

FIG 5-Summary of mean results of Neuroticism Score Questionnaire reduced to sten score for the six groups. Arrows indicate changes between admission and discharge; single symbol indicates no change.

$O=$ Physiotherapy, $O=$ controls, group $1 ; \square=$ physiotherapy, $\square=$ controls, group $2 ; \boldsymbol{\Delta}=$ physiotherapy, $\Delta=$ controls, group 3.

\section{Discussion}

An expert working party on intensive care in respiratory insufficiency unanimously concluded that physiotherapy was essential. ${ }^{12}$ We examined our results to assess the importance of physiotherapy and to find useful criteria for recovery. The single difference between the groups was sputum volume. Patients in groups 1 and 2 who received physiotherapy and IPPV had a greater sputum volume, and although all showed a decrease in the last three days, the difference within group 1 was greater for those receiving physiotherapy and was significant at the $5 \%$ level. We assumed that the decrease in sputum volume indicated clinical improvement, and interpreted the increased sputum volume of our male patients receiving physiotherapy and IPPV as being a desirable effect of that treatment. Increased sputum volume did not accelerate the improvement of patients receiving physiotherapy. The effect of physiotherapy on sputum volume remains small, and the relation between sputum volume and pulmonary function is not clear. The saline aerosol delivered by IPPV may have increased sputum volume. ${ }^{13}$ From the satisfactory results seen in our control group, administering a bronchodilator by IPPV could produce at best only a small advantage, possibly in patients with the lowest pretreatment $\mathrm{FEV}_{1}(<0.751) .{ }^{14}$ Observations of sleep and eating patterns were quantified using simple scales. Improved eating often anticipated improvement in $\mathrm{FEV}_{1}$ and $\mathrm{VC}$ by several days, and improvement in $\mathrm{PaO}_{2}$ was also gradual. A standard one-minute walking test was included to ensure equal mobilisation, and in such disabled patients walking is an integral test of cardiorespiratory function. We noted a similar correlation between our one-minute walking test and VC as was seen in a more detailed 12-minute test. ${ }^{15}$ The one-minute test allows a direct feedback of improvement to the patient. It was retrospectively evident that patients who died after leaving hospital had performed extremely poorly on this test $(<50 \mathrm{~m} / \mathrm{min})$

We were concerned that patients not receiving physiotherapy might feel deprived of treatment. NSQ personality tests did not show any hidden psychological benefit of either physiotherapy or IPPV. All our patients received considerable attention, and twice-daily spirometry may have been therapeutic; this was necessary for monitoring progress and does not negate the results in the controls. The twice-daily objective and subjective observations by the physiotherapists were useful; their role in monitoring progress should be extended. When a patient with chronic bronchitis and respiratory failure is deteriorating, emphasis on correct diagnosis, fluid electrolyte balance, and nutrition together with judicious oxygen treatment are needed. The practice of intensifying physiotherapy in these patients is not supported by the evidence.

We are grateful to Dr G F Edwards, Professor C M Fletcher, Professor M S Losowsky, and Dr Brian Payne for constructive criticism of the trial protocol; Mrs Sandra Brown, Miss Pamela Duce, Mrs Ann Shields, and Mrs Mavis Teague for secretarial help; Mr Alex Sinebruchow for scoring NSQ sheets; the physicians, nursing staff, and physiotherapists throughout St James's Hospital for their generous co-operation; the Yorkshire Regional Health Authority for financing a computer scan of reports on physical treatment in chest disease; and Mrs Greenwood for some home visits to discharged patients. Blood-gas analyses were performed by $\mathrm{Mr}$ Arnold Stephenson and his staff, who also maintained and calibrated the vitalographs. Miss Carol Barley performed the physiotherapy between 1 November 1977 and 30 January 1978, and thereafter Miss Helen Pain until 1 May 1978.

\section{References}

${ }^{1}$ Crofton, J, and Douglas, A, Respiratory Diseases, pp 18, 300. Oxford, Blackwell, 1969.

${ }^{2}$ American Thoracic Society, American Review of Respiratory Diseases, 1968, 97, 725 .

3 Pierce, A, K, and Saltzman, H A, American Review of Respiratory Diseases, 1974, 110, suppl, p 1 .

${ }^{4}$ Motley, H L, American Review of Respiratory Diseases, 1963, 88, 484.

${ }^{5}$ Campbell, E J M, and Friend, J, Lancet, 1955, 1, 325.

${ }^{6}$ Emmanuel, G E, Smith, W M, and Briscoe, W A, fournal of Clinical Investigation, 1966, 45, 1221.

${ }^{7}$ Anthonisen, P, Riis, P, and Søgaard-Andersen, T, Acta Medica Scandinavica, 1964, 175, 715 .

${ }^{8}$ Newton, D A G, and Stephenson, A, Lancet, 1978, 2, 228.

9 Medical Research Council, Lancet, 1965, 1, 775

10 Newton, D A G, and Stephenson, A, Lancet, 1978, 2, 530.

11 Gaskell, D V, and Webber, B A, The Brompton Hospital Guide to Chest Physiotherapy, 2nd edn. Oxford, Blackwell, 1973.

12 European Working Group on Respiratory Insufficiency, ICP/OCD 003, p 11. World Health Organisation, 1976.

13 Edwards, G F, et al, Chest, 1976, 70, 506.

14 Berend, N, Webster, J, and Martin, E G, British fournal of Diseases of the Chest, 1978, 72, 122.

15 McGavin, C R, Gupta, S P, and McHardy, G J R, British Medical fournal, 1976, 1, 822.

(Accepted 11 October 1978)

ONE HUNDRED YEARS AGO The fees for a complete medical education in Paris amount to 1272 francs, or about $£ 53$. A Paris degree does not at present entitle its possessor to practise in England. (British Medical fournal, 1878.) 